УДК 343.985(477)

DOI https://doi.org/10.32849/2663-5313/2019.9.38

\title{
Мар'яна Кравчук,
}

канд. юрид. наук,

дочент кафедри кримінального права та процесу

Тернопільського начіонального економічного університету

\section{ФОРМУВАННЯ БІОТЕРОРИЗМУ ЯК ФЕНОМЕНА СУЧАСНОГО СУСПІЛЬСТВА}

У статті розглянуто явище біотероризму та визначено його місие у системі розвитку біотерористичної діяльності як сочіального феномена. Застосування терористами новітніх гібридних біологічних технологій забезпечує досягнення ключових завдань тероризму щодо маніпулювання людською свідомістю, залякування населення, впливу на органи державної влади. Надано соиіальну та правову характеристики даного явища, яке визнане автором як: складна сочіальна система, детермінована взаємодією негативних факторів зовнішнього середовища й відповідних особливостей суб'єкта тероризму; а також як правова оцінка та відображення даного суспільно негативного явища у чинному законодавстві з метою забезпечення на приниипах законності удосконалення протидії біотероризму. Встановлено, що методи біотероризму у постіндустріальному суспільстві постійно удосконалюються, а суб'єкти біотерористичної діяльності опановують інновачійні механізми вчинення різного роду посягань на життя і здоров'я людей. Визначено сочіально-політичні причини зростання рівня біотерористичних загроз: міждержавне військове протистояння, прагнення злочинних елементів до політичної влади та їх об'єднання із корумпованими представниками державного апарату управління, відставання державного (адміністративного) контролю за сферою протиправної діяльності через неналежну підготовку представників правоохоронних органів. Сформульовано та запропоновано внесення змін до «Основних засад (стратегіï) державної екологічної політики України на період до 2030 року» та до інших відповідних вітчизняних нормативно-правових актів шляхом включення до них категорії «біологічний тероризм як соиіальний феномен» з метою забезпечення системного сприяння прочесу формування заходів національної системи біологічної безпеки та біологічного захисту, протидії проявам біотероризму в Україні.

Ключові слова: адміністративно-правове регулювання, біотероризм, законотворчість, соціальний феномен, стратегія, сучасне суспільство.

Постановка проблеми. Протягом тривалого часу історичного розвитку світового суспільства система боротьби з різними проявами тероризму, яка спиралася на заходи міжнародної нормативно-правової протидіі терористичній діяльності та на національні антитерористичні законодавства країн світу, не завжди досить ефективно забезпечувала функціональний захист суспільства. У різні часові періоди у різних країнах незабезпечення належного рівня протидії антитерористичним загрозам призводило до численних людських жертв, матеріальних та моральних збитків.

На сучасному етапі суспільного розвитку терористична діяльність як вид суспільно неприйнятної поведінки окремих членів суспільства, зазнала трансформацій: поодинокі прояви суспільно негативної терористичної діяльності, на боротьбі 3 якими сконцентрована основна увага органів державної влади багатьох країн світу, стали широкомасштабною терористичною загрозою планетарного масштабу.
Сучасна біотерористична діяльність грунтується на можливостях застосування новітніх гібридних біологічних технологій, що забезпечує досягнення ключових завдань тероризму - маніпулювання людською свідомістю шляхом залякування населення та впливу на органи державної влади. Тобто на сучасному етапі розвитку постіндустріального суспільства методи здійснення біотероризму постійно удосконалюються, а суб'єкти біотерористичної діяльності опановують інноваційні механізми вчинення різного роду посягань як на життя і здоров'я людей, так і на встановлення необхідного напряму процесів їх мислення, формування духовності, моралі, поглядів та уподобань.

Проведені авторські дослідження у царині адміністративно-правового забезпечення протидії біотероризму дають підстави стверджувати, що законодавчі заходи запобігання терористичній діяльності є життєво необхідною умовою подальшого існування і розвитку нашої держави та повинні формуватися з урахуванням історичного досвіду 
зародження негативних проявів даного виду терористичної діяльності у суспільстві. Тобто формування пропозицій щодо нормативно-правового регулювання протидії біотероризму повинно базуватися на історико-правовому дослідженні соціального феномена біотероризму.

Ступінь розробленості проблеми. Біологічний тероризм як явище реальної суспільно-політичної дійсності досліджується представниками сучасної науки не тільки у правовому, й у різних інших аспектах: філософському, політичному, публіцистичному тощо. Дослідники розглядають це явище в різних аспектах, даючи категорії «біотероризм» власну інтерпретацію. Натепер дослідження правових, соціальних, політичних, економічних, психологічних та інших аспектів тероризму та його складової частини - біотероризму стало предметом дослідження багатьох вітчизняних науковців, які представляють різні галузі суспільних наук, зокрема таких, як B.I. Абрамов, О.В. Губар, В.П. Ємельянов, В.А. Коростиленко, В.В. Крутов, Д.Я. Кучма, Ю.А. Лапутіна, Б.Д. Леонов, О.М. Литвак, I.I. Мусієнко, I.M. Рижов, Г.П. Синтик, [1-5] та інші. Однак окреслена автором проблема є актуальною ще й з тієї причини, що у сучасних наукових дослідженнях проглядається тенденція до нечіткого визначення меж біотерористичної діяльності, необгрунтованого ототожнення іiї з багатьма суміжними явищами дійсності. Усе це, на нашу думку, призводить до формування та запровадження суперечливого антитерористичного законодавства i, відповідно, не досить ефективної практики протидії біотероризму. Зазначені та інші фактори спонукали автора до більш детального дослідження даної проблематики.

Мета статті - на підставі історичного аналізу формування різних сфер соціального управління дослідити особливості становлення біотероризму як соціального феномена, а також запропонувати шляхи вдосконалення окремих правових норм сучасних актів вітчизняного антитерористичного законодавства для посилення рівня правового забезпечення протистояння можливим терористичним загрозам в Україні.

Виклад основного матеріалу. Проблема пошуку рівня оптимального управління соціальними процесами існувала протягом усієї історії розвитку цивілізованого суспільства. Тероризм являє собою специфічний соціальний процес, у якому головним завданням є переконання засобами насильства певної частини громадянського суспільства у правильності вибраного алгоритму соці- ального управління, обраного більшістю або, навпаки, незначною частиною членів соціуму. Успіх тероризму, як і стратегія боротьби з тероризмом, в остаточному підсумку визначається тією мірою, наскільки ця стратегія підтримується загальною масою членів суспільства. Соціальна стратегія будь-якого суспільства визначає домінуючою стратегією свого існування та розвитку неприйняття насильства як засобу вирішення соціальних внутрішньосистемних та зовнішніх конфліктів. Тобто основний принцип соціального управління в сучасному цивілізованому світі та система його адміністративно-правового забезпечення повинні формуватися без впливу насильства та інших проявів терористичних переконань.

У сучасний період міжнаціонального суспільно-політичного розвитку поряд із проблемами правового регулювання - уникнення і мінімізації незаконного збагачення та подолання бідності; ліквідації збройних конфліктів та забезпечення мирного співіснування громадян у країнах; забезпечення екологічної безпеки та позитивної демографічної ситуації тощо - досить значної актуальності набула проблема тероризму, а сучасний біотероризм являє собою складну структуру з відповідними масштабами діяльності.

Ключовим елементом сучасного біотероризму $є$ організований на високому рівні його структурний характер. Зазначена терористична діяльність у сучасних умовах характеризується глобальним розмахом, високотехнологічним оснащенням, відсутністю явно виражених державних кордонів, легалізацією доходів, отриманих злочинним шляхом тощо. Проте спробуємо розглянути основні передумови формування сучасного стану розвитку біотероризму як суспільно негативного явища, що сформувалося історично у період кінця XX та початку XXI століття у нашій державі.

Отже, проведені авторські дослідження дають підстави стверджувати, що біотероризм є соціальним феноменом та являє собою складне явище матеріального світу, прояви якого людство відчуває протягом усієї своєї історії. Використовуючи біотероризм як спосіб ведення політичної боротьби у суспільстві, окремі представники такого суспільства поступово перетворили його на явище глобального масштабу. Слід додати, що такому стану справ сприяла здатність суб'єктів біотерористичної діяльності використовувати досягнення технічного прогресу у частині різносторонньої озброєності виконавців при виборі біологічних способів впливу на якісний стан біорізноманіття. 
Поєднання нами визначення ряду усіх можливих об'єктів біотерористичного впливу в одній дефініції «біорізноманіття» пояснюється підтримкою наукової позиції правознавця I.В. Гиренко, яка зазначає, що біорізноманіття є національним багатством України. Це різноманіття живих організмів (рослин, тварин, грибів і мікроорганізмів), а також екосистем (наземних, водних морських, гірських), природних комплексів i екологічних процесів, частиною яких вони $€$. Людина $є$ невід'ємним елементом біорізноманіття і поза ним існувати не може» [6, c. 480].

Отже, досліджуючи формування біологічного тероризму як способу негативного впливу на біорізноманіття нашої держави, зазначимо таке. Перебуваючи у загальній структурі терористичної діяльності, біотероризм, за твердженням ряду науковців, давно перетнув державні кордони й став міжнародним суспільно негативним (злочинним) явищем. Аналіз учинених терористичних акцій свідчить про наявність сучасних тенденцій зміцнення зв'язків між терористичними організаціями різних країнах світу, налагодження та координації їхньої діяльності [2, с. 13].

Досліджуючи передумови вищезазначених наслідків сучасного стану організації терористичної діяльності, зазначимо, що ще у 90-х роках минулого століття науковець, політик (народний депутат України попередніх скликань Верховної Ради України), громадський діяч O.М. Литвак розглядав біотероризм як явище високого рівня небезпеки. Така терористична діяльність, за визначенням науковця, була орієнтована на масові жертви, а тому вимагала підвищення ефективності заходів для запобігання біотероризму. Також науковець зазначав, що визначення методологічної основи детермінації тероризму має безпосереднє практичне значення, оскільки від цього залежить вибір засобів попередження терористичних актів [4, с. 203].

Досліджуючи суспільно-правові засади виникнення та розвитку біотероризму, слід зазначити, що до кінця ХХ ст. основна маса населення на пострадянському просторі не сприймала належним чином проблему тероризму, а тому суспільство не формувало запит на прийняття законодавчими органами нормативно-правових актів протидії різним фактично існуючим проявам тероризму.

Досліджуючи передумови активізації терористичної діяльності після 1991 року, В.Ф. Антипенко відносить до них демократизацію (анархізацію) у колишніх тоталітарних державах (країнах Східної Європи, що утворилися на території Радянського Союзу після його розпаду) та появу нових країн 3 низьким рівнем протидії тероризму з боку правоохоронних органів тощо [7, с. 226].

Здійснені авторські дослідження мотиваційних передумов формування біотероризму в усьому світі показують, що у сучасний період на перший план часто виступають ідеї, що відображають як соціально-політичні, так і національно-територіальні (геополітичні) та релігійні інтереси. Проводячи аналіз великого спектру факторів, які впливають на можливість здійснення біотерористичної діяльності та виникнення біотерористичних загроз в Україні, можна висловити припущення про те, що передумовами для активізації такої діяльності у нашій державі можуть стати постійні процеси трансформації суспільних відносин, становлення ліберально-ринкової економіки, періодичні зміни домінування векторів політичного управління в країні та зовнішній негативний інформаційний та мілітаристичний вплив з боку сусідньої країни.

3 метою посилення доказової бази щодо необхідності вдосконалення адміністративно-правового забезпечення протидії біотероризму у нашій державі пропонуємо перелік сформованих авторкою причин, які, на їі думку, можуть безпосередньо чи опосередковано впливати на зростання рівня біотерористичних загроз:

- подальше загострення військового протистояння на Сході України, що може супроводжуватися зростанням різних видів актів терористичної спрямованості;

- об'єднання суб'єктів протиправної суспільно-економічної діяльності з корумпованими представниками державного апарату управління та їхнє прагнення до політичної влади, що сприяє переходу різних видів тероризму до засобів впливу у політичній сфері з метою розширення сфер власного впливу;

- постійне відставання державного (адміністративного) контролю за сферою протиправної діяльності через неналежну підготовку представників правоохоронної та судової системи тощо.

Отже, можна упевнено припустити, що однією з причин зародження та розвитку біотерористичної діяльності в Україні може стати недосконалість державної (адміністративної) системи соціального управління. Виходячи 3 цього, окремими членами суспільства, які незадоволені станом суспільноекономічного розвитку держави та власним фінансово-економічним становищем, біотероризм може розглядатися як форма соціального протесту проти влади з її офіціальною системою адміністративного управління та примусу. 
На нашу думку, рівновага між членами суспільства як суб'єктами права та державною владою повинна забезпечуватись виваженою правовою політикою, що передбачає можливість корегування способів, методів та прийомів політичного управління відповідно до наданих у встановленому чинним законодавством порядку рекомендацій та побажань. Прояви біотерористичної діяльністі у нашій державі можуть виникнути як наслідок незгоди та соціального протесту окремих членів суспільства проти встановленого порядку управління. Тобто біотерористична діяльність може стати реакцією на соціальний конфлікт.

Отже, використовуючи вищевикладені результати дослідження та спираючись на надбання представників правової науки у царині дослідження загальної проблематики протидії тероризму, таких як В.А. Коростиленко, Б.Д. Леонов, І.М. Рижов, та інших [2], пропонуємо авторське тлумачення дефініції «біологічний тероризм як соціальний феномен», визначаючи його як процес нав'язування окремим громадянам чи суспільству в цілому, незалежно від принципів його організації, способу соціального управління або його примусової зміни шляхом проведення або погрози проведення проти населення з метою загрози його знищення біотерористичних дій насильницького характеру (з використанням біологічних засобів: бактерій, вірусів, грибків, токсинів або речовин, вироблених цими організмами), які здатні викликати широкий суспільний резонанс на основі віртуального страху або фактичного знищення максимальної кількості людей та інших елементів біорізноманіття.

На нашу думку, доцільним є включення визначення «біологічний тероризм як соціальний феномен» до «Основних засад (стратегіï) державної екологічної політики України на період до 2030 року», яка затверджена Законом України від 28 лютого 2019 року № 2697-VIII та набере чинності з 01.01.20120 p. [8]. Авторська аргументація внесення доповнень до законодавства грунтується на таких аргументах. У цій Стратегії окреслено наявні проблеми сучасного стану довкілля в Україні (Розділ 1 Стратегії) та наголошено на тому, що процеси глобалізації та суспільних трансформацій потребують від України вжиття термінових заходів, зокрема, в частині підвищення рівня біологічної безпеки, що вимагає системних заходів зі створення та ефективного функціонування національної системи біологічної безпеки та біологічного захисту, протидії проявам біотероризму, створення системи раннього виявлення та швидкого реагування на поширення збудників особливо небезпечних хвороб та таких, що мають міжнародне значення, а також покращення матеріально-технічного стану лабораторій, установ та закладів, які здійснюють діагностику інфекційних хвороб, моніторинг циркуляції збудників інфекційних хвороб в об'єктах середовища життєдіяльності людини, задіяні в системі індикації біологічних патогенних агентів, лабораторій, що працюють зі збудниками особливо небезпечних інфекційних хвороб, визначенням їх впливу на навколишнє природне середовище, зокрема біологічного різноманіття, з урахуванням ризиків для здоров'я людини; створення системи оперативного реагування на прояви біотероризму.

На нашу думку, охарактеризована Стратегія, яка містить нормативні приписи про протидію біотероризму як засобу негативного впливу на біологічне різноманіття з урахуванням ризиків для здоров'я людини, повинна, однак не містить визначення поняття «біологічний тероризм як соціальний феномен», яке є важливим для подальшого правозастосування, проте відсутне у будь-якому чинному нормативно-правовому акті.

\section{Висновки}

Отже, біотероризм є складним багаторівневим негативним явищем сучасної дійсності, яке посягає на різні сфери життєдіяльності людей, тому попередження, протидія та боротьба з ним являє собою одну 3 найскладніших проблем теорії і практики сучасного адміністративно-правового регулювання суспільних відносин.

Аналіз історичного досвіду формування біотероризму як суспільно негативного явища сучасної дійсності дає підстави розглядати його таким чином: 1) як негативне соціальне явище, що являє собою складну соціальну систему, детерміновану взаємодією негативних факторів зовнішнього середовища й відповідних особливостей суб'єкта тероризму; 2) як правову оцінку та відображення даного суспільно негативного явища у чинному законодавстві; 3) як здійснення процесу вдосконалення на принципах законності практики протидії біотероризму.

На нашу думку, авторські результати дослідження, зокрема визначення дефініції «біологічний тероризм як соціальний феномен», повинні знайти своє відображення у трансформованому Законі України «Про основні засади (стратегію) державної екологічної політики України на період до 2030 року» та інших нормативно-правових актах вітчизняного законодавства, яке визначатиме основні засади протидії біотероризму в Україні. 
Досліджуючи поняття біотероризму як соціального феномена й надалі, важливо прагнути до того, щоб його формулювання не давало приводу до сучасних суспільнополітичних спекуляцій. Крім того, зазначена категорія повинна визначатися такими конкретними правовими ознаками, які б не дозволяли легко маніпулювати цим поняттям і довільно його вживати, що дуже важливо не тільки для наукових досліджень, але й для законотворчої та правозахисної практики.

\section{Список використаних джерел:}

1. Губар О.В. Організаційно-правові засади функціонування системи забезпечення біологічної безпеки України. Науково-інформаиійний вісник Академії начіональної безпеки. 2016. Вип. 3-4 (11-12). С. 143-155.

2. Коростиленко В.А., Леонов Б.Д., Рижов I.M. Тероризм: визначення і сутність : монографія за заг. ред. В.В. Крутова, І.І. Мусієнка, В.П. Ємельянова. Київ : Нац. акад. СБУ, 2015. 192 с.

3. Лапутіна Ю.А. Світовий досвід організації та правового забезпечення протидії біологічному тероризму. Міжвідомчий медичний журнал «Наука і практика». 2014. № 1 (2). С. 17-21.

4. Литвак О.М. Тероризм: соціально-психологічний аспект. Тероризм і боротьба з ним : міжвідомчий науковий збірник / під ред. А.І. Комарової та ін. Київ, 2000. Т. 19 (1). С. 202-205.

5. Синтик Г.П., Абрамов В.І., Кучма Д.Я. Концептуальні засади забезпечення національної безпеки України : навчальний посібник : у 3 ч. Ч. 1. Філософсько-методологічні та системні основи забезпечення національної безпеки. Київ : НАДУ, 2009. $248 \mathrm{c}$

6. Екологічне право України. Загальна частина : навчальний посібник / Курзова В.В., Берлач А.І., Бондар Л.О. Гиренко I.I. та ін.; за ред. В.І. Курила. Київ : Алерта, 2015. 620 с.

7. Антипенко В.Ф. Борьба с современным тероризмом: международно-правовые подходы. Киев : НБУВ; Юнона-М, 2002. 712 с.

8. Основні засади (стратегія) державної екологічної політики України на період до 2030 року : Закон України від 28.02.2019 № 2697-VIII (набере чинності з 01.01.2020). URL. : ttps:// zakon.rada.gov.ua/laws/show/2697-19? find=1\&tex $\mathrm{t}=\% \mathrm{E} 1 \% \mathrm{~B} 3 \% \mathrm{EE} \% \mathrm{~F} 2 \% \mathrm{E} \% \mathrm{~F} 0 \% \mathrm{EE} \% \mathrm{~F} 0$ (дата звернення: 12.08.2019).

The article deals with the phenomenon of bioterrorism and identifies its place in the system of bioterrorist activity development as a social phenomenon. The use of the latest hybrid biological technologies by terrorists ensures the achievement of the key tasks of terrorism in the manipulation of human consciousness, intimidation of the population and influence on public authorities. The social and legal characteristics of this phenomenon, which is recognized by the author as: a complex social system, determined by the interaction of negative environmental factors and relevant features of the subject of terrorism; as well as the legal assessment and reflection of this socially negative phenomenon in the current legislation in order to ensure, on the principles of legality, the improvement of counter-terrorism. It has been established that the methods of bioterrorism in the post-industrial society are constantly being improved, and the subjects of bioterrorist activity are mastering innovative mechanisms of committing various kinds of attacks on the life and health of people. The socio-political reasons for the increase in the level of bioterrorist threats are identified: interstate military confrontation, the desire of criminal elements to political power and their association with corrupt representatives of the state apparatus of administration, the backlog of state (administrative) control over the sphere of illegal activity due to inadequate training of law enforcement representatives. Formulated and proposed changes to the "Basic Principles (Strategy) of the State Environmental Policy of Ukraine for the Period up to 2030" and to other relevant domestic legal acts, by including the categories "biological terrorism as a social phenomenon" in order to provide systematic assistance to the process formation of measures of the national system of biological safety and biological protection, counteraction of manifestations of bioterrorism in Ukraine.

Key words: administrative and legal regulation, bioterrorism, lawmaking, social phenomenon, strategy, modern society. 